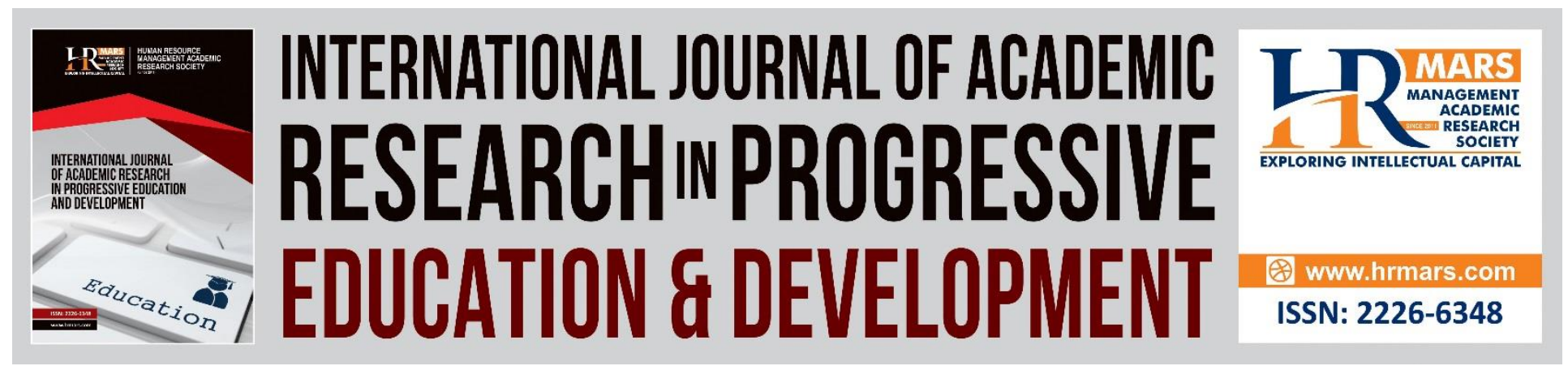

\title{
Career Transition Practice from Student Development Aspect: Best Practices in the Implementation of Special Skills Certificate Program in Malaysian Community College
} Ardzulyna Anal, Aznan Che Ahmad, Abd Rahim Razalli, Low Hui Min

To Link this Article: http://dx.doi.org/10.6007/IJARPED/v7-i4/4841 DOI: $10.6007 /$ IJARPED/v7-i4/4841

Received: 17 Sept 2018, Revised: 03 Nov 2018, Accepted: 09 Nov 2018

Published Online: 17 Nov 2018

In-Text Citation: (Anal, Ahmad, Razalli, \& Min, 2018)

To Cite this Article: Anal, A., Ahmad, A. C., Razalli, A. R., \& Min, L. H. (2018). Career Transition Practice from Student Development Aspect: Best Practices in the Implementation of Special Skills Certificate Program in Malaysian Community College. International Journal of Academic Research in Progressive Education and Development, 7(4), 122-133.

\section{Copyright: (c) 2018 The Author(s)}

Published by Human Resource Management Academic Research Society (www.hrmars.com)

This article is published under the Creative Commons Attribution (CC BY 4.0) license. Anyone may reproduce, distribute, translate and create derivative works of this article (for both commercial and non-commercial purposes), subject to full attribution to the original publication and authors. The full terms of this license may be seen at: http://creativecommons.org/licences/by/4.0/legalcode

\section{Vol. 7, No. 4, 2018, Pg. 122 - 133}




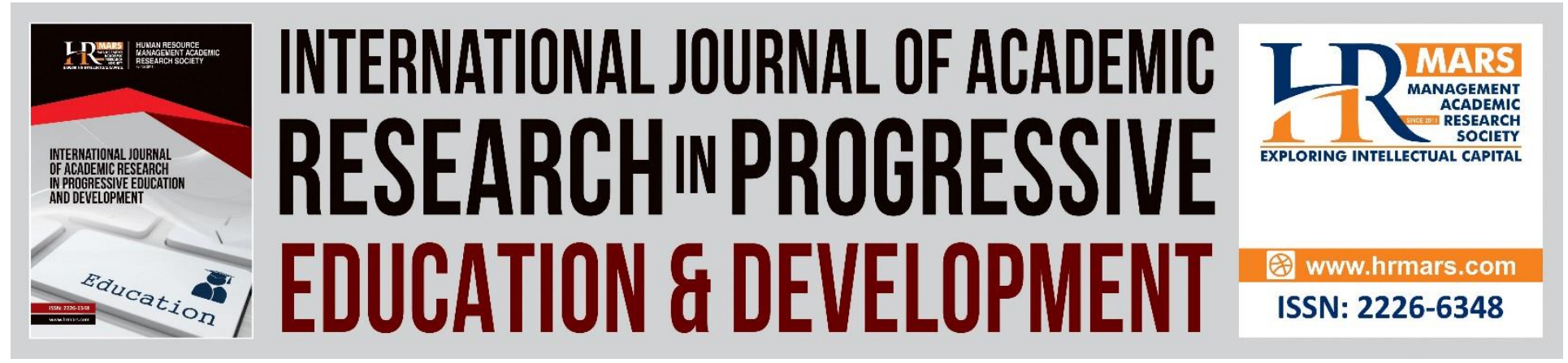

\title{
Career Transition Practice from Student Development Aspect: Best Practices in the Implementation of Special Skills Certificate Program in Malaysian Community College
}

\author{
Ardzulyna Anal ${ }^{1}$, Aznan Che Ahmad², Abd Rahim Razalli ${ }^{1}$ \\ Low Hui Min² \\ ${ }^{1}$ Faculty of Human Development, Universiti Pendidikan Sultan Idris \\ ${ }^{2}$ School of Educational Studies, Universiti Sains Malaysia
}

\begin{abstract}
For every human being, career is essential in ensuring a better quality of life. This similarly applies to disabled people who are born with disabilities, be it physical, visual, sensory, intellectual or any other disabilities that make them face various challenges to ensure that they are able to obtain career opportunities appropriate to their abilities. This situation led to the need to conduct a study aimed at exploring the best practices in the transition practice to career in terms of student development, especially students with disabilities from the perspective of lecturers at Selayang Community College who are involved in teaching the Special Skills Certificate Program. Qualitative approach with case study design was used in this research. The researcher used the in-depth interview method using semi structural interview questions to collect data. For the purpose of selecting respondents, the researcher used a purposive sampling technique involving three lecturers. The findings show that elements such as the teaching of living skills, careerrelated teaching and working experience are among the best practices that need to be applied effectively in the implementation of a career transition so that these special need students are adequately equipped to go to work. At the end of the research, researchers also suggested several other approaches for further research in the area of career transition.
\end{abstract}

Keywords: Career transition, Special Skills Certificate Program, Community College

\section{Introduction}

Tiun and Khoo (2013) research on employability among disabled workers (OKU) in Malaysia show that issues of discrimination and exploitation at work, mobility problems, transportation problems to work locations, and difficulty in finding suitable jobs are among the key challenges faced by this group of people. Despite the various opportunities provided by the employer on 

DEVELOPMENT

Vol. 7, No. 4, 2018, E-ISSN: 2226-6348 ๑ 2018 HRMARS

social awareness of the people with disabilities, it has always been common for employers to choose the best candidates for a position to be offered (Mohd Zulkarnain Abdul Wahab, Aliza Alias \& Hamidah Yamat, 2017). In fact, most of the jobs offered by today's employers have outlined the criteria which in essence emphasize the educational background and certain experience to offer such as the scope of work required by the employer. This situation is difficult for disabled people to get a job and ultimately causes the gap of this minority to get a job getting bigger.

For some researchers who look into career issues for disabled people in Malaysia, it is agreed that career development for disabled people should be paid attention even at school level especially in education programs that provide skills such as career transition programs and so on. For example, Aliza Alias (2014) research finds that the lack of working experience in the industry among special need students is a factor that contributes to difficulties in adapting to a new environment, weakness in communication skills (including communication with employers, colleagues and customers as well as difficulty understanding the direction) and negative behavior in completing the assignment. Furthermore, Fazlinda Ab Halim (2013) research finds that the moderate level of skill and self-esteem of disabled students in Malaysian higher education institutions also contributes to the challenges in their career development. While from the perspective of Kumaresan Muniandy and Noraini Salleh (2017), lack of training related to any field of work and competition issues in securing the limited available jobs also serve as challenges for these OKUs to get a better career future. Looking at the above situations, these factors are all seen as a matter of gap in the development of students which are supposed to be instilled through the career transitional practices at the school level and subsequently the career realm. This is in line with the results of Mazzoti, Rowe, Cameto, Test, and Morningstar (2013) study which explains that career success in the true context of OKUs is determined by the quality of education and training experience received before hopping into the career world.

Internationally, the Individuals with Disabilities Education Act (IDEA, 2004) emphasizes the need for a career transition program among special needs students which emphasizes more on the co-ordination of activities that are more focused on the progress of students in the process of transition from one educational level to a career realm. Based on Mazzotti et al., (2013), the career transition program is a comprehensive program that contains lessons and components of the services needed by a student or student with special needs to help them achieve their education, career and life goals independently. Based on a research conducted by Aliza Alias (2014), through the transition program to this career, these disabled students will benefit in terms of acquiring experience in certain fields of work, obtaining educational opportunities that suit their ability and potential, and getting trained in a skill-focused education program through the use of technical and vocational curricula instead of following the existing academic curriculum. This shows that students with special needs who have academic problems due to the inevitable inability can still be trained through a skill-focused education system so that they will also have the opportunity to get a career that suits their ability, thus to have a better quality life in the future.

\section{Special Skills Certificate Program at Community College}

The Disability Action Plan (2016-2022) proposed by the Ministry of Women, Family and Community Development (2016) targets to further increase by 10 percent of the number of 
Vol. 7, No. 4, 2018, E-ISSN: 2226-6348 @ 2018 HRMARS

existing special need pupils attending the existing career transition program. By 2025, the Ministry of Education Malaysia (2013) has targeted the increase in tertiary education enrollment rates from $36 \%$ to $53 \%$ to be equivalent to the highest level of enrollment in other ASEAN countries. Hence, the development of a new system in education today has focused on the path of technical and vocational training education. As such, the role of community colleges becomes increasingly important today as an institution recognized by the Department of Skills Education to handle skills training and offer Malaysian Skills Certification for specific areas and skill levels based on Skills Standards National Occupation (NOSS).

Now, the role of a community college as an institution that provides access to education through its provision of extensive training and skills to the society has been extended to disadvantaged students. Until 2015, out of 94 community colleges in Malaysia, 13 have successfully opened the full-time Special Skills Certificate Program to special need students in the category of learning problem (Department of Community College Studies, 2015). In 2007, Selayang Community College has opened the Special Skills Certificate Program of Basic Culinary to students with hearing problems and to date, Selayang Community College has become the first and only community college to offer Special Skills Certificate Program to students with special needs. Through this program, the special need students are offered Levels 1 and 2 of Skill Certificate Malaysia (SKM) based on their ability. This provides a path for these students which allows them training and skills to be pursued for their careers later. Therefore, this study is aimed at exploring and identifying the best practices in the career transition in terms of the development of special need students from the point of view of lecturers as a result of the implementation of the Special Skills Certificate Program at the Selayang Community College. It is anticipated to be a guide for a more effective transition program in the future.

\section{Research Method}

In conducting this study, the researcher used a qualitative approach, specifically the case study design in order to explore deeply respondents' views and experiences in the practices. The main data gathering technique was in-depth interviews. In this study, Selayang Community College was chosen because this community college was the first and only community college in Malaysia that offered the Basic Culinary Skill Certification Program to students with hearing-impairment and learning problems. Therefore, purposive sampling was conducted. Three lecturers with more than 8 years of teaching experience in the Special Skills Certificate Program at this community college were selected. In collecting the data, the researcher conducted a face-to-face interview with each respondent using semi-structured interview questions. The results of the interview were recorded and transcribed. Then, the researcher performed the transcript revision process before coding the data into several themes.

\section{Results}

In the context of the Special Skills Certificate Program for Basic Culinary at this community college, the best practices of career transition from the aspect of student development can be discussed based on the findings of this study: The teaching of living skills, career-focused teaching, and preparation for working experience, application of assessment elements and provision of support systems. 
(a) The Teaching of Living Skills

From the elements of living skills, interviews with lecturers showed that teachings on self-reliant skills, personal skills, communication and social skills as well as sports and recreation skills were essential in the implementation of a career transition. These can be proven through the following interviews.

(R1): "Although we are aware of the challenges faced by our students, to learn to live independently, we need to encourage them to live in dorms with other normal students so that they can and will survive with any challenges or problems to adapt, socialization and communication issues as well as emotional problems, especially in the first semester of students in this community college".

(R2): "We have to make sure that the personality of the students is nurtured as well as it is important for their career development ... employers prefer to take our students with good characters, attitudes and ethics. Through the Islamic Education and Moral Education courses, we can apply spiritual, manners and limitations in intercourse, applying pure values in personal life and emphasizing the safety and personal hygiene aspects of each student".

(R3): "We are implementing sports and recreation skills in co-curricular activities ... In cocurriculum we also teach first aid, healthy eating styles and proper care and management aspects, at the same time we also uncover and glitter the talents that are within them. Among them, some have succeeded in being the representative of this college in several national sporting events".

\section{(b) Career-Focused Teaching}

Referring to the development of students in the implementation of the Special Skills Certificate Program for Basic Culinary at this community college, interviews with lecturers showed that the curriculum structure does not only focus on culinary related subjects but also other courses like Bahasa Melayu, Basic Computing and Basic Entrepreneurship for their career needs.

(R1): "Basic Culinary related courses such as Basic Western Cooking, Basic Malaysian Cooking and Pastries, all are taught 'hands-on' before the students undergo industrial training. The skills taught in the field begin at level 1 and level 2 only (basic) which are sufficient for career needs in this course ..."

(R2): "Not only in culinary courses, we also provide courses such as Malay Language, The Basic of Computer Application and The Basic of Entrepreneurship as an additional requirement for careers".

(R3): "In the subjects of Malay Language, they are taught on how to prepare resumes, write letters to apply for jobs and learn basic skills to attend a job interview. In computing subjects, they are taught to search information about the types of dishes, ingredients and recipes ... without expecting full information from the lecturers".

(c) Provision of Work Experience

Of the implementation of the Special Skills Certificate Program for Basic Culinary, students are given the opportunity to experience working in a structured working environment and obtain a 


\section{INTERNATIONAL JOURNAL OF ACADEMIC RESEARCH IN PROGRESSIVE EDUCATION AND}

DEVELOPMENT

Vol. 7, No. 4, 2018, E-ISSN: 2226-6348 @ 2018 HRMARS

reward from the work or assignment. Based on the interviews with the lecturers, the working experience obtained by students from the Selayang Community College's Special Skills Certificate Program were based on both entrepreneurship programs and industrial training.

(R1): $\quad$ "The entrepreneurship program at Inspired Kitchen which has been created in this college has given students experience about managing restaurants. They themselves cook, manage their own restaurant and make sure this restaurant gets good responses from customers ...."

(R2): "Working experience in entrepreneurship programs has helped to boost student self-confidence and enable students to learn about career and ethical values while working. Our students cook more and more. Hopefully after graduation, they can be independent, know how to cook ... how to survive, can plan for business ..."

(R3): $\quad$ "Training in the industry can raise the confidence of students in which students are given the opportunity to experience their own situations of the environment and real job challenges. Here, we can assess the overall level of their skills in the field of Basic Culinary. In addition, they can learn many new things and know more people, add and learn the skills learned in college, learn to solve their own problems, learn to follow the instructions, control emotions and discipline, be more responsible in doing something, learning to live independently and with the salary they receive, they are more motivated ..."

\section{(d) Application of Assessment Element}

Referring to the interviews with the three lecturers, the assessment element should be implemented as best as possible in the course of career transition in terms of student development. For example, in the implementation of this Special Skills Certificate Program for Basic Culinary at this community college, the present assessment consists of two approaches, namely evaluation carried out in the teaching and learning and assessment in industrial training. The interview with the respondents supported the findings of this research.

(R1): "... we have continuous individual assessments of each culinary course where the instrument we use is the Work Rubric Procedure and the Practical Product Outcome".

(R2): "The weightage of 70 percent practical evaluation and the 30 percent final exam evaluation to be consistent with the application of career-based learning approaches". The assessment includes Assignment 1 (20\%), Quiz 1 (20\%), Practice 1 (30\%) and Practice 2 (30\%).

(R3): "... as students work in industrial training, we need to collect the students' development information on aspects of technology utilization skills, communication skills, social skills and teamwork, compliance with policies, procedures and company regulations, ethics and reporting. Evaluation is based on the results of discussions and feedback from employers ..." 
INTERNATIONAL JOURNAL OF ACADEMIC RESEARCH IN PROGRESSIVE EDUCATION AND DEVELOPMENT

Vol. 7, No. 4, 2018, E-ISSN: 2226-6348 @ 2018 HRMARS

\section{(e) Provision of Support System}

Support system is one of the elements applied in the implementation of the Special Skills Certificate Program for Basic Culinary at this community college to help optimize students' progress as they go through the career transition. The interviews with the following lecturers have proven that there are several support system approaches that have been implemented in this program in the effort to improve the student development.

(R1): "The presence of the Lecturer of Resources and Sign Language as a reference to lecturers and special education students in this community college and become a source of support in teaching and learning. The Sign Language master is not only a translator of instructional content, but he also engages in any program that involves special education students such as a week of experience, job interviewing and intermediaries in matters involving collaboration between students hearing problems with the industry and often being a consultant to lecturers".

In addition, through this in-depth interview, the researchers found that teaching and learning aids play important roles in the implementation of the Special Skills Certificate Program for Basic Culinary at this community college. Among the support system provided is to ensure that the infrastructure for teaching and learning is able to meet the needs of students learning. This is especially in accordance with individual capabilities and the industry's specification of facilities so as to optimally improve students' progress. Therefore, Lecturer 2 (R2) asserted that "if you want to open the program to $O K U$, make sure that the infrastructure is adequate and according to the student's specification, for example light signal is placed on the oven for to cater for the need of students with hearing problem. We also modify some incomplete equipment ourselves so as not to interfere with the teaching and learning process ...".

Besides, the interview with Lecturer 3 (R3) showed that pocket money allowance is also a form of support system provided at this community college. With the aim of providing financial assistance to students whose family income is below RM3000, this serves as an incentive for these students to continue their studies until they graduate.

The most important findings showed that effective support systems can be well provided as a result of good support and acceptance from the top management. This can be proven through interviews with all lecturers who agree with the fact that the support from the top management is key to the success of a transition program into this career. In-depth information on top administrative roles has been proven through interviews with the following lecturer.

(R2): "Administrative support is especially important in terms of financial allocation for additional infrastructure, solid and adequate human resource capacities, training and professionalism amongst staff ...".

From the point of view of the lecturers, information resources are among the most important aspects of the support system. Much support accessible to the people with disabilities is hampered by the disclosure of information which does not reach the community. This situation can eventually lead to a negative implication on social awareness among Malaysians. This statement can be explained more profoundly from the following interview finding.

(R3): "Actually many parents and employers do not know about the employee's allowance but the information does not come to the employer ... another one is about tax, it's okay to issue double redundant tax as this is not a problem 
INTERNATIONAL JOURNAL OF ACADEMIC RESEARCH IN PROGRESSIVE EDUCATION AND DEVELOPMENT

Vol. 7, No. 4, 2018, E-ISSN: $2226-6348$ @ 2018 HRMARS

anymore to employers. The problem now is that the employer did not know. This

makes it difficult for employers to hire disabled students to work with them".

Discussing the implications of information resource gap, the interview with Lecturer 2 (R2) shows that the lack of information disclosure cause many parents, especially of students undergoing the Special Skills Certificate Program for Basic Culinary at the community college, to complain about the difficulty to find suitable workplace and employers who are willing to accept their children to undergo industrial training. The complaints also include long-distance workplace and students undergoing industrial training in the workplace that is not in line with their field and their level of capability. As a result, this situation has caused parents to experience high levels of stress in dealing with the challenges faced by their children. This leads some parents and family members to decide on letting their children stay at home without doing any work.

\section{Discussion}

Referring to the implementation of the Special Skills Certificate Program for Basic Culinary at this Community College, interviews have shown that the teaching of living skills, career-focused teaching skills, preparation of work experience, application of assessment and support systems are among the elements that need to be implemented in the practice of career transition that can improve student development, especially among individuals with special needs. This is supported by the results of previous research which highlight living skills (Apellman, Callahan, Luetke \& Deborah, 2012), skill-based teaching that focuses on the field of career (Wehman, 2013), work experience (Aliza Alias, 2014), assessment elements (Karahalis, 2011) and the provision of support system (Lazaroff, 2013) as possible factors that can influence the effectiveness of the career transition program.

According to Lindstrom, Doren and Miesch (2011), emphasis on living skills teaching should not be underestimated in ensuring the career transition among these special need individuals. Life management instruction allows these special need students to live independently without expecting dependence on others. This statement can be demonstrated through the effectiveness of the approach by encouraging students of Special Skills Certificate Program for Basic Culinary to stay at the hostel with other normal students. This is seen as one of the best practices that can be applied in enhancing the development of special students in self-reliance skills, adaptive skills, socialization, communication and emotional management skills as well as life management skills such as the ability to manage self-esteem, provide food, manage time, maintain personal safety, interpersonal skills and intrapersonal skills. The results of this research are supported by Paju, Raty, Pirttimaa and Kontu (2016) who found that special need students with exposure of an inclusive environment are seen to experience living independently and to learn to adapt to the community life.

Subsequently, in delivering a lecture on career fields, the results of the interview with lecturers showed that educators and sign language teachers play important roles in ensuring effective delivery. For example, in this Special Skills Certificate Program for Basic Culinary, the researcher found that the expertise and extensive experience possessed by lecturers and sign language instructors serve as the strength of this program. It enables the career-based learning to be a real-world experience, considering the ability of the students to be seen as the catalyst for the effectiveness of the skills delivered to the students. The researcher finds all the challenges that exist among students with learning problems and hearing impairment - such as differences 
INTERNATIONAL JOURNAL OF ACADEMIC RESEARCH IN PROGRESSIVE EDUCATION AND DEVELOPMENT

Vol. 7, No. 4, 2018, E-ISSN: 2226-6348 ๑ 2018 HRMARS

in attitudes, levels of ability and disabilities, interests and tendencies - are considered different from each other requiring an educator to get involved in the career transition program. This is to ensure that these students master the field-related skill, speaking competency and endurance toward challenges. This is supported by Scheetz (2012) that educators and sign language instructor who are involved in teaching students with hearing problem should have a good level of language skills and competence and be able to handle the challenges and obstacles faced by each student so that what is learned can be mastered and understood more effectively.

Apart from the emphasis on career-related teaching, Aliza Alias (2014) strongly stresses on the exposure of career experience that should be given to students with special needs in the implementation of a career transition program. Referring to the results of the interviews with all three lecturers, the researcher found that the career experience gained by the students of the Special Skills Certificate Program at this community college (through entrepreneurship programs and work experience in industrial training) is seen to be beneficial for the students in preparing them for the challenge of real work. Through these approaches, these learners are not only able to apply practical knowledge and theories studied in the classroom but can also help to improve their behavioral and emotional skills, communication skills with colleagues and customers, gain experience on managing businesses from an early stage, boost self confidence in dealing with society, learn values and ethics while working through direct experience as well as enhance selfreliance before undergoing industrial training. For example, through industrial training, the research finds that the career experience gained by these students is actually helpful in gaining direct work experience thereby enhancing self-confidence in applying the skills, enabling the level of overall skill being assessed as well as preparing students to deal with various career challenges.

As for the assessment element, according to interviews with the lecturers, teaching and learning assessments using the Procedure of Working Rubric and Practical Product Evaluation Assessment tool are among forms of assessment that enable lecturers to obtain and collect information on individual student development in terms of attitudes and safety, work procedures, product results and hygiene. In addition, students are also evaluated with other forms of assessment such as formative and summative assessments conducted in the forms of quizzes, individual or group assignments. Assessment in industry training is an assessment using a checklist evaluating and collecting student progress in terms of the level of technology utilization, communication skills, social skills and teamwork, company policies, procedures and regulations, ethics and reporting. This information is also obtained through employers' observation and feedback during the industrial training. According to Karahalis (2011), assessment is one of the most important elements that can influence the effectiveness of a career transition program of special need students. In the absence of assessments to obtain information on the level of transitional skills among students of the Special Skill Certificate Program, the researcher found that the lecturers had difficulty obtaining specific information about the level of transition skills which eventually led to the difficulty in setting the direction of students' career placement that corresponds to their level of capability and functionality.

According to Albertini, Kelly and Matchett (2011), the provision of a good support system is not only important to the development of these special need students in education, but also affect their future career development. Looking at the Special Skills Certificate Program for Basic Culinary at this community college from the support system aspect, interviews with lecturers showed that the Resources Lecturer and the sign language instructors play important roles for 


\section{INTERNATIONAL JOURNAL OF ACADEMIC RESEARCH IN PROGRESSIVE EDUCATION AND}

DEVELOPMENT

Vol. 7, No. 4, 2018, E-ISSN: 2226-6348 @ 2018 HRMARS

the students. The services of the sign language instructor are required as to cater for students with hearing problems. This is particularly in attending matters pertaining to instructional content, in-person engagement, managing job interviews, and intermediaries in matters involving collaboration between student hearing problems with the industry. Meanwhile, the services from the resource lecturer are needed to assist and facilitate lecturers, students and family members managing matters related to the support of teaching and learning needs, students' financial aid, discipline management, and counseling services.

In addition, accommodation in this learning support also plays an important role in ensuring effective teaching and learning in accordance with individual student's needs. Therefore, in implementing such a program, the administration of the college and the lecturers should ensure that the provided infrastructure is adequate and according to the specifications of each student inability to avoid interrupting the teaching and learning process. For example, the oven signals are modified by putting a light as signs to facilitate the students with hearing problems in using the equipment to perform tasks in the kitchen. Furthermore, financial assistance is also one of the support systems required by a small number of students, especially students coming from low income families. Through the granting of this money allowance, the students of the Special Skills Certificate Program for Basic Culinary are qualified for financial assistance in order to survive to pursue their studies until graduation.

In providing an effective support system approach, interviews with all lecturers showed that the top administrative support of an institution implementing a career transition program plays an important role. Among the necessary administrative support include the preparation and acquisition of appropriate financial resources, particularly in the purchase of high-tech materials and equipment, additional infrastructure, additional human resource capacity and the provision of training and professionalism among staffs. Therefore, the researcher sees that the level of knowledge, understanding and acceptance of the superior administration of the needs of the disabled is one of the most important factors in providing an effective support system in a career transition program.

Finally, the most important findings of this study show that information resources also play an important role in the implementation of career transition practices. For example, in this study, the lecturer stated that many employers do not want to hire OKU because they are less likely to get exposed to accurate information about people with disabilities in Malaysia and the actual characteristics of students with special needs in terms of cognitive and other developments. According to the lecturers interviewed, the lack of exposure to information on various initiatives and benefits provided by the Ministry of Women and Community Development on employers who employed these disabled workers such as the Disabled Worker's Allowance (EPC), and other initiatives related to tax relief and deductions from the Revenue Board Domestic Affairs has implicated the development of careers for the disabled in Malaysia. Thus, it is not surprising that a handful of employers still underestimate the capabilities of the disabled and there is a discrimination issue in terms of payroll. Even interviews with lecturers also found that the implications of this information resource constraint also causes most parents to have difficulty in finding job placement that fit their field and ability. This causes pressure and concern among parents towards the future of their child's career after graduation. 


\section{Conclusion}

Due to certain issues in the context of disabled students career development, many researchers choose to get involved in this area of career transition such as Finn and Kohler (2009); Test, Fowler, Ritcher, White, Mazzoti, Walker and Kortering (2009); Mazzotti, Test and Mustian (2014); Wehman (2013); Miller (2013); Mackay (2014) and Flexer, Baer, Luft and Simmons (2013). These researchers suggest that more research on career transition practices based on the Kohler Model be used to identify the effectiveness of transitional programs in their respective countries. This is to ensure improved transition programs according to the suitability of policies, cultures and educational systems in their respective countries. This is evidenced by Finn and Kohler (2009) research findings that many states in America have referred to the Kohler Model as a guideline in implementing a career transition program. As for future studies, the researcher suggests that the practice of career transition amongst students with special needs is not only seen from the perspective of the practice approach (in terms of the development of the student), but be viewed in depth from other aspects like student-focused planning, family involvement, inter-agency collaboration and program structure to ensure effective career transition program amongst students with special needs in the country.

\section{Corresponding Author}

Ardzulyna Anal, Universiti Pendidikan Sultan Idris, Malaysia, Email: ardzulyna@fpm.upsi.edu.my

\section{References}

Albertini, J.A., Kelly, R.R., \& Matchett, M.K. (2012). Personal factors that influence deaf college students' academic success. Journal of Deaf Studies and Deaf Education, 17(1): 85-101.

Alias, A. (2014). Transition program: The challenges faced by special needs students in gaining work experience. International Education Studies, 7 (13):192-196.

Appelman, K.I., Callahan, J.O., Mayer, M.H., Luetke, B.S., \& Deborah, S.S. (2012). Education, employment, and independent living of young adults who are deaf and hard of hearing. American Annals of the Deaf, 157 (3): 264-275.

Halim, F. A. (2013). Kemahiran kebolehgajian, estim kendiri dan efikasi kendiri pelajar teknikal dan vokasional yang bermasalah pendengaran di politeknik dan kolej komuniti, Malaysia. (Tesis Doktor Falsafah). Universiti Putra Malaysia.

Finn, J. E., \& Kohler, P.D. (2009). A compliance evaluation of the transition outcomes project. Career Development for Exceptional Individuals, 32(1): 17-29. doi 10.1177/0885728808315332.

Flexer, R.W., Baer, R.M., Luft, P., \& Simmons, T.J. (2013). Transition planning for secondary students with disabilities. (Fourth Edition). Upper Saddle River, New Jersey: Pearson Education, Inc.

Karahalis, J. (2011). Coherence and compliance of Kohler's model for successful transition planning with classified special education students. Retrieved from November 24, 2015 daripada http://search.proquest.com/docview/1018542545 ?accountid=13155.

Lazaroff, K.C. (2013). A study of teachers' perceptions of school-level factors affecting transition services. Doctoral thesis, University of North Carolina. 
INTERNATIONAL JOURNAL OF ACADEMIC RESEARCH IN PROGRESSIVE EDUCATION AND DEVELOPMENT

Vol. 7, No. 4, 2018, E-ISSN: 2226-6348 @ 2018 HRMARS

Lindstrom, L., Doren, B., \& Miesch, J. (2011). Waging a living: career development and long-term employment outcomes for young adults. Exceptional Children, 77 (4): 423-434.

Mackay, J. L. (2014). Post-secondary transition planning for students with disabilities: developing a roadmap to success. (Doctoral thesis). College of Saint Elizabeth.

Mazzoti, V.L., Rowe, D.A., Cameto, R., Test, D.W., \& Morningstar, M.E. (2013). Career Development for Exceptional Individuals, 36 (3):140-151.

Mazzotti, V. L., Test, D. W., \& Mustian, A. L. (2014). Evidence based practices and predictors: Implications for policy makers. Journal of Disability Policy Studies, 25: 5-18. doi: $10.1177 / 1044207312460888$.

Miller, V. (2013). The quality and effects of secondary transition plans on special education graduates' postsecondary outcomes and their effects on secondary transition. (Doctoral thesis). Gardner-Webb University School of Education.UMI Number: 3589100.

Paju, B., Raty, L., Pirttimaa R., \& Kontu, E. (2016). The school staff's perception of their ability to teach special educational needs pupils in inclusive settings in Finland. International Journal of Inclusive Education, 20 (8): 801-815. doi: 10.1080/13603116.2015.107473.

Scheetz, N.A. (2012). Deaf education in the 21st century topics and trends. Upper Saddle River, New Jersey: Pearson Education, Inc.

Wehman, P., (2013). Transition from school to work: where are we and where do we need to go?. Career Development and Transition for Exceptional Individuals, 36(1): 58-66. 